\title{
Peningkatan Margin Kontribusi dan Nilai Tambah Aneka Produk Olahan Rumput Laut di Desa Bungin Permai, Konawe Selatan, Sulawesi Tenggara
}

\section{(The Improvement of Contribution Margin and Added Value of Various Seaweed-Processed Products in Bungin Permai Village, South Konawe, Southeast Sulawesi)}

\author{
Ine Fausayana ${ }^{1 *}$, Rosmawaty ${ }^{1}$, Akhyar ${ }^{2}$ \\ 1 Program Studi Agribisnis, Fakultas Pertanian, Universitas Halu Oleo, Kampus Hijau Bumi Tridharma, \\ Anduonohu, Kambu, Kota Kendari, Sulawesi Tenggara 93232. \\ 2 Program Studi Ilmu Sosial Politik, Fakultas Ilmu Sosial dan Ilmu Politik, Universitas Halu Oleo, \\ Kampus Hijau Bumi Tridharma, Anduonohu, Kambu, Kota Kendari, Sulawesi Tenggara 93232. \\ *Penulis Korespondensi: inefausayana@ymail.com \\ Diterima Agustus 2018/Disetujui Januari 2019
}

\begin{abstract}
ABSTRAK
Kegiatan Program Kemitraan Masyarakat (PKM) ini dilaksanakan di unit usaha petani rumput laut UMKM Kumbang Laut dan Sinar Laut di Desa Bungin Permai, Kecamatan Tinanggea, Kabupaten Konawe Selatan, Sulawesi Tenggara. Kelompok ini masing-masing beranggotakan 10 orang yang melakukan usaha aneka olahan rumput laut. Permasalahan yang dihadapi oleh kedua mitra adalah masih terbatasnya introduksi teknologi dan kemampuan manajemen usaha sehingga berdampak pada rendahnya margin kontribusi dan nilai tambah. Kegiatan ini bertujuan untuk meningkatkan margin kontribusi dan nilai tambah aneka produk olahan rumput laut. Hasil kegiatan menunjukkan bahwa nilai produksi yang dihasilkan produk es krim dan nugget pisang rumput laut masing-masing sebesar Rp 80.000. Perbandingan margin kontribusi sebesar Rp 40.340 dan 37.550. Nilai tambah setelah diolah sebesar 37.740 dan 31.050, sehingga nilai tambah yang dihasilkan per $1 \mathrm{~kg}$ rumput laut kering untuk masing-masing produk adalah Rp 188.700 dan 155.250.
\end{abstract}

Kata kunci: margin kontribusi, nilai tambah, produk olahan, rumput laut

\begin{abstract}
This Community Partnership Program (CPP) activity was implemented in the seaweed farming business unit in Bungin Permai Village, Tinanggea District, South Konawe District, Southeast Sulawesi. The Community Partnership Program (PKM) activity is carried out in the seaweed farmer's business unit UMKM Kumbang Laut and Sinar Laut in Bungin Permai Village, Tinanggea District, South Konawe Regency. Each group consists of 10 people who carry out various seaweed processing businesses. The problems of UMKM is the limited introduction of technology and business management capabilities so that it has an impact on the low contribution margin and added value. This activity aims to increase the contribution margin and the added value of various processed seaweed products. The results showed that the production value seaweed ice cream and seaweed banana nuggets was IDR 80,000 each. Comparison of contribution margins was IDR 40,340 and IDR 37,550. Added value after processing amounted to 37,740 and 31,050 . So the added value produced per $1 \mathrm{~kg}$ of dried seaweed for each product is IDR 188,700 and IDR 155,250 .
\end{abstract}

Keywords: contribution margin, processed products, seaweed, value added

\section{PENDAHULUAN}

Rumput laut atau makro algae sudah sejak lama di Indonesia dikenal sebagai bahan makanan tambahan, sayuran, dan obat tradisional. Rumput laut menghasilkan senyawa koloid yang disebut fikokoloid, yakni agar, align, dan karaginan (Kadi 2004; Handayani et al. 2004). Jenis rumput laut banyak dimanfaatkan karena mempunyai komposisi kandungan yang lengkap seperti karbohidrat yang tinggi, 25-35\% protein dari berat kering, mineral (terutama iodine), lipid, sterol, asam amino, omega-3 \& omega-6, anti-oksidan, hormon pertumbuhan, polifenol, dan flavonoid serta vitamin C (Suparmi \& Sahri 2009; Dewi 2012). Hasil Kajian Ilalqisny dan Widyartini (2000) bahwa sejak tahun 2700 SM rumput laut telah dimanfaatkan sebagai bahan pangan. 
Berdasarkan data statistik di Sulawesi Tenggara terdapat beberapa kabupaten yang potensial untuk pengembangan rumput laut. Konawe Selatan merupakan kabupaten terbesar penghasil produksi rumput laut jenis Eucheuma cottonii. Produksi sejak tahun 2013 sampai dengan tahun 2016 (ton) berturut-turut adalah $105.072,00 ; 100.710,00 ; 151.547,56$; dan 193.729,69 penyumbang produksi terbesar adalah dari Desa Bungin Permai, Kecamatan Tinanggea. Terdapat 11 kelompok penghasil rumput laut di Desa Bungin Permai. Kelompok ini berasal dari komunitas Bajo yang disebut "Sama" (artinya sesama komunitas etnik Bajo) dan dari kelompok luar etnik Bajo yang disebut "Bagai". Kelompok Kumbang Laut dan Sinar Laut adalah dua di antaranya. Setiap kelompok memiliki 10 anggota petani rumput laut dengan produksi antara 500-2.500 kg rumput laut kering per musim tanam per petani ( 1 tahun maksimal 4 kali MT). Hampir semua kelompok tani menjual rumput lautnya dalam bentuk gelondongan, meskipun anggota Kelompok Kumbang Laut dan Sinar Laut pernah mendapatkan introduksi teknologi dari perguruan tinggi ataupun dari instansi terkait, tetapi belum ada satupun anggota kelompok yang menjadikannya sebagai usaha produktif karena keterbatasan introduksi teknologi yang diperoleh dan sarana prasarana yang dimiliki, demikian halnya dengan pengelolaan manajemen usaha masih lemah.

Aspek produksi rumput laut dan manajemen usaha untuk kelompok ini dapat ditingkatkan dari usaha gelondongan rumput laut kering menjadi usaha komersial dengan mendiversifikasi menjadi produk-produk komersial dan bernilai ekonomi tinggi. Diversifikasi usaha diharapkan dapat meningkatkan margin kontribusi dan nilai tambah komoditi rumput laut yang dihasilkan. Beberapa kajian mengenai hasil rumput laut menunjukkan bahwa melalui proses lanjutan dapat meningkatkan nilai tambah pada komoditi rumput laut (Subhan 2014; Dharma et al. 2016; Sulistyaningsih \& Puryantoro 2017). Sedangkan analisa margin kontribusi produk telah dilakukan oleh Oktaviani dan Effendi (2014) serta Silvana et al. 2014.

Berdasarkan permasalahan kedua mitra dan potensi rumput laut yang ada di desa Bungin Permai maka perlu dilakukan kegiatan pengabdian pada UMKM Kumbang Laut dan Sinar Laut di Desa Bungin Permai. Kegiatan ini bertujuan untuk meningkatkan margin kontribusi dan nilai tambah aneka produk olahan rumput laut.

\section{METODE PELAKSANAAN KEGIATAN}

Program ini dilaksanakan di Desa Bungin Permai, Kecamatan Tinanggea, Kabupaten Konawe Selatan, Provinsi Sulawesi Tenggara pada unit usaha pengolahan rumput laut, yaitu pada UMKM Bintang Laut dan Sinar Laut. Kedua UMKM ini terdiri dari ibu-ibu, ibu kepala rumah tangga, dan remaja putri yang kesehariannya membantu suami, anak, dan orang tua dalam budi daya rumput laut. Hasil dari kegiatan pengabdian diukur dengan menggunakan margin kontribusi dan nilai tambah.

Margin kontribusi (contribution margin), atau laba marginal (marginal income), adalah selisih antara pendapatan penjualan dengan semua biaya variabel. Margin kontribusi dihitung dengan cara mengurangkan biaya variabel, baik untuk biaya produksi maupun nonproduksi dari penjualan (Carter 2009). Menurut Supriyono (2004) contribution margin adalah pendapatan penjualan dikurangi semua biaya variable. Contribution margin (CM) dapat dihitung dengan dua cara, yaitu:

CM per unit = harga jual per unit - biaya variabel per unit (1)

$\mathrm{CM}$ total $=$ pendapatan penjualan - biaya variabel total (2)

Produk memberikan nilai tambah apabila terdapat selisih antara penjualan dan biaya variable setelah dilakukan pengolahan produk rumput laut. Sedangkan laba perusahaan dalam jangka pendek dipengaruhi oleh penerimaan dan total biaya (Mulyadi 2009)

\section{Materi Bimbingan Teknis}

Metode pelaksanaan kegiatan terkait dengan tahapan atau langkah-langkah yang digunakan pada produksi adalah bersifat praktis, sederhana, murah, dan aplikatif. Materi bimbingan teknis meliputi pemilihan bahan baku dan bahan penolong, peralatan yang digunakan, komposisi bahan dan perhitungan meramu bahan serta pembuatan (prosessing) adonan, pengemasan, dan pemasaran

Tahapan dalam melaksanakan solusi dari permasalahan mitra terdiri dari beberapa tahap, yaitu tahap I, persiapan penyuluhan pendataan UMKM yang akan terlibat dalam kegiatan. Tahap II, pengadaan bahan-bahan dan peralatan untuk produksi olahan rumput laut. Tahap III, pelaksanaan produksi olahan rumput laut (es pisang ijo, brownies, dan es krim), demonstrasi dan pelibatan langsung UMKM serta pengujian kua- 
litas hasil produksi. Tahap IV, evaluasi dan monitoring setiap kegiatan.

\section{Metode Pendekatan}

Metode pendekatan yang ditawarkan untuk menyelesaikan persoalan mitra yang telah disepakati bersama untuk kedua aspek utama dalam kurun waktu realisasi program PKM adalah:

- Metode technology transfer. Model ini digunakan untuk membantu dalam mengolah dan mengembangkan produksi melalui penerapan teknologi tepat guna yang mudah diperoleh, mudah dioperasionalkan dan murah sehingga dapat dijangkau dengan menerapkan cara produksi makanan yang baik (CPMB). Proses produksi yang akan diberikan adalah teknik pengendalian mutu produk mulai dari bahan baku sampai produk jadi, termasuk pengemasan dan labeling.

- Metode enterpreunership capacity building (ECB), yaitu membantu kelompok dalam membentuk jiwa wirausaha yang profesional, baik dalam teknis maupun dalam pengelolaan manajemen.

\section{HASIL DAN PEMBAHASAN}

\section{Gambaran Umum Lokasi}

Kegiatan pengabdian Program Kemitraan Masyarakat (PKM) dilakukan di Desa Bungin Permai yang merupakan salah satu desa dari 24 desa yang ada di Kecamatan Tinanggea. Desa ini terletak $5 \mathrm{~km}$ ke arah selatan dari ibu kota Kecamatan Tinanggea. Desa Bungin Permai memiliki luas $\pm 5 \times 15 \mathrm{~km}^{2}=75 \mathrm{~km}^{2}$ berada di atas permukaan air laut sehingga dikenal dengan sebutan desa terapung dan berbatasan dengan desa-desa di sekitarnya di mana sebelah utara berbatasan dengan Desa Akuni, timur berbatasan dengan Desa Torokeku, selatan berbatasan dengan Selat Tiworo, dan barat berbatasan dengan Roraya. Desa Bungin Permai sendiri mayoritas di huni oleh etnik Bajo yang pada umumnya berprofesi sebagai petani rumput laut dan nelayan tangkap. Jumlah penduduk Desa Bungin Permai sebanyak 1.398 jiwa atau $417 \mathrm{KK}$, terdiri dari epat dusun. Dusun I, II, dan III mayoritas penduduknya adalah petani rumput laut sedangakan Dusun IV mayoritas sebagai nelayan tangkap dan sebagian petani rumput laut.

Jarak tempuh dari Kota Kendari ke Kecamatan Tinanggea sekitar $120 \mathrm{~km}$ dengan menggunakan transportasi darat. Jarak tempuh dari Kecamatan
Tinanggea ke Desa Bungin Permai sejauh 3 km dengan menggunakan transportasi laut atau perahu motor (masyarakat setempat menyebutnya sebagai ojek laut).

Jumlah petani rumput laut di Desa Bungin permai sebanyak 296 orang. Produksi rumput laut kering yang dihasilkan rata-rata sebanyak $1.255 \mathrm{~kg}$ per musim tanam atau sebesar $5.019 \mathrm{~kg}$ per tahun (dalam setahun 4 kali musim tanam). Mayoritas petani menjual rumput lautnya dalam bentuk gelondongan (berupa bibit dan rumput laut kering).

\section{Profil Mitra Kelompok Tani.}

Kegiatan PKM ini melibatkan dua kelompok UMKM, yaitu UMKM Kumbang Laut dan Sinar Laut. Setiap UMKM memiliki 10 orang anggota kelompok. Kedua UMKM ini termasuk petani rumput laut dan keluarganya sehingga di dalam kelompok ada anggota pria, tetapi fokus introduksi pengolahan melibatkan anggota ibu-ibu dan remaja putri. Seperti halnya masyarakat lainnya di desa tersebut, kelompok ini juga menjual rumput laut dalam bentuk gelondongan. Meskipun kedua kelompok ini pernah mendapat pelatihan dari instansi terkait, tetapi belum menjadikan usaha ini sebagai usaha yang produktif.

\section{Tahapan Pemberdayaan Kelompok Mitra - Persiapan}

Pada tahap persiapan ini masing-masing kelompok mengidentifikasi anggota yang akan terlibat dalam kegiatan. Tahap ini dilakukan pada bulan April 2018 dengan menanyakan keseriusan anggota untuk melaksanakan kegiatan dan mau berusaha untuk dapat menjadikan kegiatan ini sebagai kegiatan usaha komersial dan dapat bertanggungjawab terhadap pelaksanaan kegiatan. Setelah mengidentifikasi anggota, langkah selanjutnya adalah mengidentifikasi bahan dan alat yang dibutuhkan oleh masing-masing UMKM.

\section{- Penyiapan bahan-bahan dan peralatan untuk produksi olahan rumput laut}

Pada tahap ini kegiatan yang dilakukan adalah penyiapan bahan-bahan untuk pembuatan aneka olahan rumput laut. Rumput laut yang dipilih adalah dari jenis Eucheuma cottonii. Bahan rumput laut semua diadakan di lokasi pengabdian, sedangkan bahan yang lain juga diadakan di lokasi pengabdian kecuali bahan seperti tepung roti, cokelat krim atau cokelat batang dan whippy diadakan di Kota Kendari. Bahan pendukung lainnya semua diadakan di lokasi pengabdian. Pemilihan bahan baku yang digunakan disesuai- 
kan dengan pangsa pasar. Khusus untuk produk es krim rumput laut maka bahan bakunya disesuaikan dengan pangsa pasarnya.

Pemilihan bahan baku rumput laut dilakukan dengan cara memilih rumput laut yang kadar garam dan kotoranya rendah. Rumput laut kering merupakan bahan baku dasar untuk semua produk olahan yang diintroduksikan (Gambar 1). Pengadaan alat produk es krim didatangkan dari Jakarta, sedangkan alat lainnya diadakan di Kendari di lokasi pengabdian.

\section{Pelaksanaan Produksi Olahan Rumput Laut}

Pada tahap ini dilakukan bimbingan teknis pembuatan es krim, pisang ijo, brownies dan nugget pisang yang berbahan dasar rumput laut. Demonstrasi dilakukan dengan pelibatan langsung UMKM Kumbang Laut dan Sinar Laut. Introduksi teknologi yang diberikan pada kedua UMKM meliputi pembuatan es krim.

Pembuatan es krim rumput laut pada dasarnya sama dengan pembuatan es krim pada umumnya, tetapi diberi tambahan rumput laut. Es krim rumput laut yang dibuat disesuaikan dengan pangsa pasar es krim. Proses pembuatan es krim rumput laut yaitu, pertama rumput laut yang telah melalui perendaman diblender hingga halus lalu dimasak hingga mendidih. Langkah kedua mikser telur dan gula hingga mengembang. Langkah ketiga mikser bahan es krim (whippy) dengan air es. Langkah keempat masak susu cair dengan cokelat bubuk yang telah tercampur rata lalu dinginkan. Langkah kelima campur adonan whippy, kuning telur, dan gula pasir ke dalam adonan susu cair dan cokelat bubuk. Langkah keenam aduk semua adonan (kecuali rumput laut) di atas wajan dan masak kembali dengan api kecil. Langkah ketujuh, setelah adonan dingin masukkan adonan rumput laut lalu campur hingga merata. Langkah terakhir masukkan ke dalam mesin mikser es krim.

Bahan untuk membuat semua olahan rumput laut menjadi aneka produk diambil dari rumput laut kering kemudian di rendam dalam air beras selama 3-4 hari. Hasil rendaaman $1 \mathrm{~kg}$ rumput laut menghasilkan $10 \mathrm{~kg}$ rumput laut basah (rasio 1:1). Gambar 2 menunjukkan proses pembuatan es krim rumput laut dan nugget pisang rumput laut pada kelompok usaha Kumbang Laut dan Sinar Laut. Gambar 3 menunjukkan hasil olahan rumput laut.

Peluang usaha produksi olahan rumput laut yang dapat dihasilkan oleh Kelompok Kumbang Laut dan Sinar Laut dapat dilihat pada Tabel 1 dan 2. Pada Tabel 1 dan 2 biaya bahan baku
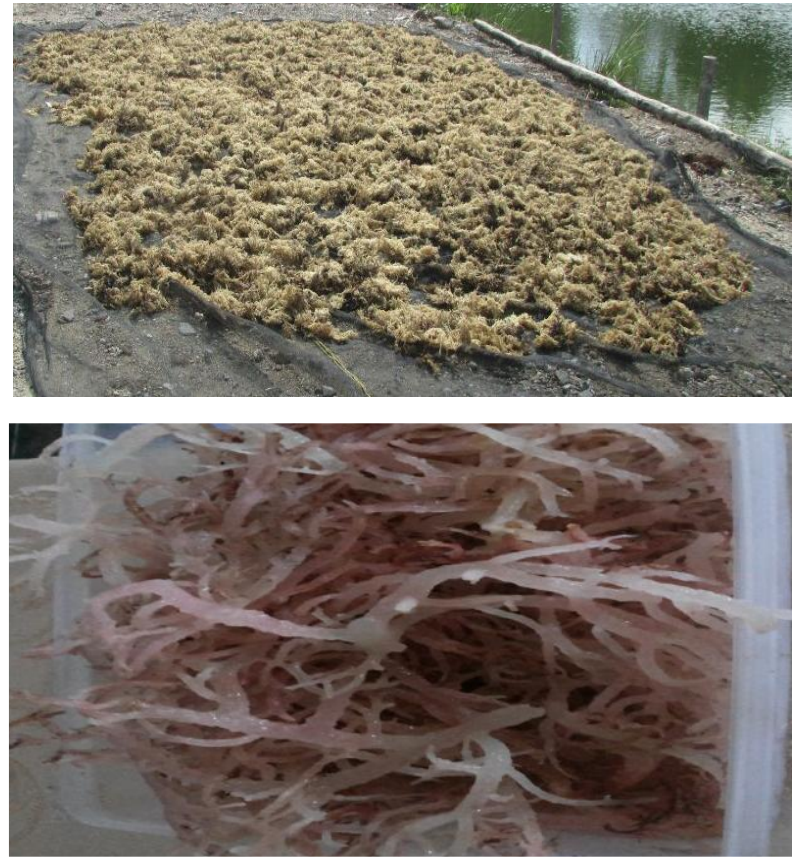

Gambar 1 Rumput laut kering dan rumput laut setelah direndam 4 hari.
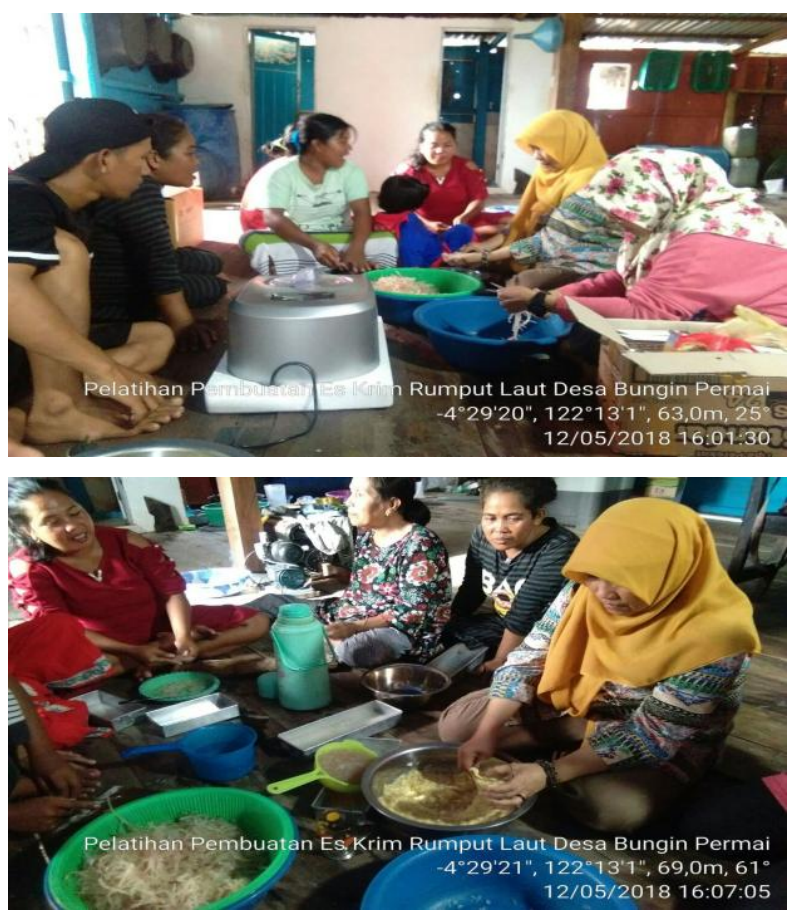

Gambar 2 Pembuatan es krim rumput laut dan nugget pisang rumput laut.

ditambah biaya pengemasan dan bahan bakar untuk es krim rumput laut dan pisang nugget rumput laut, yaitu Rp 39.660 dan 42.450. Nilai produksi yang dihasilkan masing-masing sebesar Rp 80.000. Margin usaha sebesar Rp 40.340 dan Rp 37.550. Nilai tambah setelah diolah sebesar 37.740 dan 31.050. Sehingga nilai tambah yang dihasilkan per $1 \mathrm{~kg}$ rumput laut kering untuk masing-masing produk adalah Rp 188.700 dan 155.250 . 

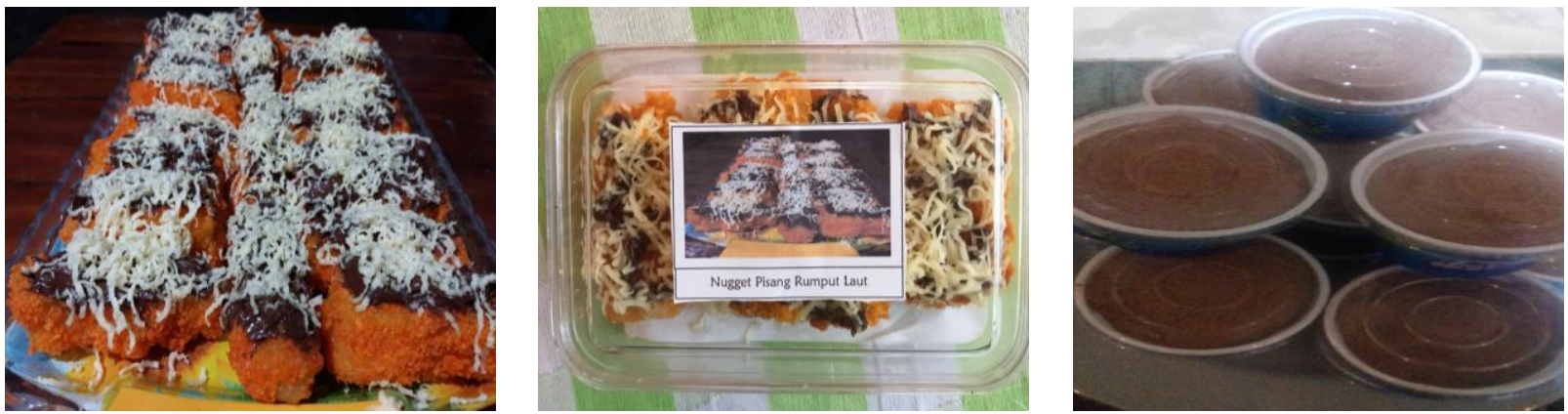

Gambar 3 Nugget pisang dan es krim rumput laut.

Tabel 1 Perbandingan nilai tambah (gelondongan dan setelah dilakukan pengolahan) produk es krim rumput laut

\begin{tabular}{|c|c|c|c|}
\hline Jenis biaya & Satuan (unit) & Harga (Rp) & Biaya produksi \\
\hline \multicolumn{4}{|l|}{ Bahan es krim rumput laut } \\
\hline Rumput laut basah & $0,02 \mathrm{~kg}$ & 13.000 & 260 \\
\hline Gula pasir & $0,2 \mathrm{~kg}$ & 12.000 & 2.400 \\
\hline Whippy atau bahan es krim $200 \mathrm{~g}$ & $0,2 \mathrm{~kg}$ & 60.000 & 12.000 \\
\hline Coklat bubuk $200 \mathrm{~g}$ & $0,2 \mathrm{~kg}$ & 12.500 & 2.500 \\
\hline Telur & 3 butir & 1.500 & 4.500 \\
\hline Susu cair $175 \mathrm{~mL}$ & 2 buah & 1.500 & 3.000 \\
\hline \multicolumn{4}{|l|}{ Kemasan dan bahan bakar } \\
\hline Kemasan luar & 20 eksamp & 500 & 10.000 \\
\hline Bahan bakar & 0,25 unit & 20.000 & 5.000 \\
\hline Total biaya & & & 39.660 \\
\hline Nilai produksi & 20 buah & 4.000 & 80.000 \\
\hline Margin kontribusi per $200 \mathrm{~g}$ & & & 40.340 \\
\hline \multicolumn{4}{|l|}{ Nilai tambah } \\
\hline Pendapatan gelondongan & $0,2 \mathrm{~g}$ & 13.000 & \\
\hline Nilai tambah setelah diolah & $200 \mathrm{~g}$ & & 37.740 \\
\hline Nilai tambah per $1 \mathrm{~kg}$ & 37,740 & 5 & 188.700 \\
\hline
\end{tabular}

Tabel 2 Perbandingan margin (gelondongan dan setelah dilakukan pengolahan) produk nugget pisang rumput laut

\begin{tabular}{|c|c|c|c|}
\hline Jenis biaya & Satuan (unit) & Harga (Rp) & Biaya produksi \\
\hline \multicolumn{4}{|l|}{ Bahan nugget pisang } \\
\hline Rumput laut basah & $0,05 \mathrm{~kg}$ & 13.000 & 650 \\
\hline Gula pasir & $0,2 \mathrm{~kg}$ & 12.000 & 2.400 \\
\hline Pisang kepok & 1 sisir & 12.000 & 12.000 \\
\hline Terigu & $0,02 \mathrm{~g}$ & 2.500 & 500 \\
\hline Telur & 2 butir & 1.500 & 3.000 \\
\hline Tepung roti & $0,1 \mathrm{~kg}$ & 10.000 & 1.000 \\
\hline Cokelat cair & $0,1 \mathrm{~kg}$ & 12.000 & 1.200 \\
\hline Keju & $0,1 \mathrm{~kg}$ & 22.000 & 2.200 \\
\hline Minyak goreng & 0,31 & 15.000 & 4.500 \\
\hline \multicolumn{4}{|l|}{ Kemasan dan bahan bakar } \\
\hline Kemasan luar & 20 buah & 500 & 10.000 \\
\hline Bahan bakar & 0,25 unit & 20.000 & 5.000 \\
\hline Total biaya & & & 42.450 \\
\hline Nilai produksi & 40 buah & 2.000 & 80.000 \\
\hline $\begin{array}{l}\text { Margin kontribusi per kg } \\
\text { Nilai tambah }\end{array}$ & & & 37.550 \\
\hline Pendapatan gelondongan & $0,5 \mathrm{~g}$ & 13.000 & 6.500 \\
\hline Nilai tambah setelah diolah & $200 \mathrm{~g}$ & & 31.050 \\
\hline Nilai tambah per $1 \mathrm{Kg}$ & 30,200 & 5 & 155.50 \\
\hline
\end{tabular}




\section{SIMPULAN}

Kegiatan PKM pada kelompok tani rumput laut UMKM Kumbang Laut dan Sinar Laut terdapat peningkatan margin kontribusi dan nilai tambah pada produk es krim rumput laut dan nugget pisang rumput laut, sehingga dengan adanya diversifikasi akan membantu petani khususnya pada saat musim paceklik.

\section{UCAPAN TERIMA KASIH}

Penulis menyampaikan ucapan terima kasih kepada Direktorat Riset dan Pengabdian Masyarakat Direktorat Jenderal Penguatan Riset dan Pengembangan Kementerian Riset Teknologi dan Pendidikan Tinggi atas dana hibah pengabdian Program Kemitraan Masyarakat (PKM) Tahun 2018.

\section{DAFTAR PUSTAKA}

Carter WK. 2009. Akuntansi Biaya. Jilid 1 Edisi ke14. Jakarta (ID): Salemba Empat.

Dharma IGBS, Dewi APWK, Darmasetiyawan IMS. 2016. Pelatihan Pengolahan Produk Rumput Laut Untuk Mendukung Pengembangan Nusa Lembongan Sebagai Destinasi Wisata. Jurnal Udayana Mengabdi. 15(2): 131-135.

Dewi R. 2012. Potensi Sumberdaya Rumput Laut. Jurnal Harpodon Borneo. 5(2): 125-129.

Handayani T, Sutarno T, Setyawan AD. 2004. Analisis Komposisi Nutrisi Rumput Laut Sargassum crassifolium. Biofarmasi. 2(2): 4552.
Ilalqisny I, Widyartini. 2000. Makroalga. Purwokerto (ID): Universitas Jendral Soedirman. $153 \mathrm{Hlm}$.

Kadi A. 2004. Potensi Rumput Laut Dibeberapa Perairan Pantai Indonesia. Oseana. XXIX(4): 25-36.

Mulyadi. 2009. Akutansi Biaya. Edisi 5. Yogyakarta (ID): STIE YKPN.

Oktaviani R, Effendi R. 2014. Pengaruh Biaya Produksi Variabel Dan Efisiensi Operasi Terhadap Margin Kontribusi (Studi Kasus Pada Sumber Bangunan Palembang). Jurnal Akuntansi. 3(1): 1-7.

Silvana F, Sudjana N, Wijono T. 2014. Analisis Contribution Margin Untuk Menentukan Tingkat Penjualan Produk Dalam Rangka Memaksimalkan Laba (Studi Pada Perusahaan Timbangan $\mathrm{X}$ Kota Malang). Jurnal Administrasi Bisnis (JAB). 15(2): 1-7.

Subhan HA, 2014. Analisis Pendapatan Dan Nilai Tambah Dodol Rumput Pada Industri Cita Rasa di Kelurahan Tinggede Kabupaten Sigi. $E$ Jurnal Ilmu Pertanian Agrotekbis. 2(5): 495499.

Sulistyaningsih, Puryantoro. 2017. Peningkatan Nilai Tambah Rumput Laut Menjadi Olahan Bakso Di Desa Gelung Kecamatan Panarukan. Paradharma (Jurnal Aplikasi IPTEK). 1(1): 15.

Suparmi, Sahri A. 2009. Mengenal Potensi Rumput Laut: Kajian Pemanfaatan Sumber Daya Rumput Laut Dari Aspek Industri Dan Kesehatan. Majalah Ilmiah Sultan Agung. 44(118): 95-116.

Supriyono. 2004. Akuntansi Biaya: Pengumpulan Biaya Dan Penentuan Harga Pokok. Yogyakarta (ID): BPFE. 